\title{
Decisions to Stay or Leave an Abusive Relationship: A Case Study Research of Dating Violence in Salatiga, Indonesia
}

\author{
Sutarto Wijono, Arianti Ina Restiani Hunga, Stefanus Perangin-Angin \\ \{sutartown@yahoo.com, airhunga@gmail.com, stefanus.kho@gmail.com\} \\ Faculty of Psychology, Universitas Kristen Satya Wacana, Jl. Diponegoro 52 - 60, Salatiga 50711, \\ Indonesia
}

\begin{abstract}
This research aims to explore dating violence phenomena that occur in young adults in Indonesia. A case study approach is used to investigate four participants' decision to stay or leave abusive relationships that they experience. Ethological perspective of attachment theory and transpersonal psychology are used as theoretical underpinnings for this research. Through in-depth interviews, it was found that two participants decided to stay in abusive relationships because of lack of attachment security with parents in the past and misperception of dating concept. Secondly, it was found that spiritual transformation of two other participants was key element that helped them to leave and move on. In conclusion, this research has two implications. Firstly, as prevention for dating violence in youth, children must have secure attachment and relation with their parents as their primary figure of attachments. Secondly, spirituality can play important role in helping individuals to move on from abusive relationships.
\end{abstract}

Keywords: dating violence; gender; ecological model; intimate partner violence

\section{Introduction}

Violence against women has become commonly reported in mass media. Research report from World Health Organization (WHO) stated that violence against women spread, internalized, and penetrated every layers of society and social classes [1]. The report revealed that one of three women in the world would experience either physical or sexual abuse in her lifetime from someone familiar and close to her, including husband, romantic partner, family members, or peers. Furthermore, WHO also mentioned that dating violence has grown into an epidemic problem in the modern world, making it one of the most prevalent problems in today's society [1].

Dating violence can be in a form of sexual violence, threats of physical or sexual violence, psychological violence, and physical violence [2]. Dating violence has become serious issue in public health and is associated with adverse physical and psychological health outcomes [3]-[5]. Survey from United States' National Intimate Partner and Sexual Violence indicated that more than 1 in 4 men $(28.5 \%)$ and more than 1 in 3 women $(35.6 \%)$ have experienced physical and/or psychological violence by an intimate partner (including dating partner) in their lifetime [5]. According to this survey, 69\% of female victims and 53\% of male victims have experienced dating or intimate partner violence before the age of 25 [5].

Empirical data in Indonesia also supported the statements that dating violence and intimate partner violence (IPV) has become a major issue in this country [6]. In Indonesia, the National Commission for Violence Against Women noted 119,107 dating abuse cases 
occurred in 2011 [7]. In 2013, compared to the previous two years, there had been a considerably significant increase in violence against women in Indonesia and $71 \%$ of the dating abuse cases in that year, happened in personal sphere. Personal sphere dating abuse is defined as cases in which the convict is still related to the victim through bloodline, marriage, or romantic relationship [8]. This data proves that violence against women does not occur exclusively on married or committed partners. It can also occur in dating relationships. In addition, from 2014 to 2017, there were an increase of violence against women cases reported to the National Commission from 293,220 cases in 2014 to 348,446 cases in 2017 [9]-[12]

Dating violence and IPV are associated with adverse mental health outcomes such as post-traumatic stress disorder, depression, anxiety, somatic complaints and anger/hostility [4], [5], [13]. Moreover, dating violence is also associated with negative behaviors that can contribute negatively to physical and mental health, such as risky sexual behavior and increased use of substance such as alcohol, tobacco, and drugs [14], [15]. Another negative consequence of dating violence is the potential of an individual/victim to establish unhealthy/abusive relationship patterns that can increase risk for further additional abuse exposures in the future [14].

There are several factors which hinders the victims to part from their partners, including past memories, commitment and emotional attachment, economic dependence, how long they have been dating, abusers' dominating power, fear of further abuse, and lack of support from family or peers [16]-[20]. In terms of motivation to stay in an abusive/unhealthy relationship, according to the Theory of Planned Behavior (TPB) that was developed in 1985 by Icek Ajzen, there are three factors that influence motivation and intention to stay and remain in a relationship. Namely, attitudes about dating violence, subjective norms about dating violence, and perceived control over dating violence prevention [21]. According to Ajzen [21] and Peterson [22], if a woman has permissive attitudes towards dating violence, has wrong perception about dating norms, and has lower perceived control over one's dating violence situation, it is more likely that the woman will intent and choose to stay in the current abusive/unhealthy relationship.

From ethological perspective of attachment theory, previous findings from John Bowlby showed that intimacy and closeness between family members could create a secure attachment between each one of them [23]. Bowlby defined intimacy as a relationship between two individuals, such as an infant and a parent, who develops strong feeling and willingness to continue in a close, intimate relationship [24], [25]. Bowlby, in Santrock [23], termed this close and intimate relationship as a secure attachment between a child and his/her parent. On the contrary, according to Bowlby, in Santrock [23] a type of attachment relationship that he coined as insecure attachment could also occur between a child and his/her parent. Insecure attachment that an individual experienced during childhood could lead to the individual's occurrence of dating abuse victimization in the future [24], [26]. This is occurred because family functioning and home environment are very essential for individual's attachment. Previous research from Foshee et al. [27], and Vagi et al. [28] showed that high levels of family conflict in the home environment, poor family functioning, divorce, lack of parental supervision, and poor parent-child communication in an individual's childhood were all associated with increased risk of insecure/unhealthy attachment patterns and dating violence occurrence in the future, whether as a victim or a perpetrator. Furthermore, exposure to violence at home during childhood or witnessing domestic violence has particularly strong effect on the future victimization and/or perpetration of violence [29].

TPB can also be applied as a theoretical framework for Transpersonal Psychology. Davis explained that transpersonal psychology is defined as a study towards the highest possible 
potentials with an acknowledgement, understanding, and realization of consciousness which unite spiritual and transcendence [30]. Transpersonal psychology deals with emphasis on empirical research on responsible implementations from relevant discoveries in selfactualization, self-transcendence, consciousness, and transcendental phenomenon which occurs (or experienced) by individuals or groups. According to TPB [22], if a woman has negative attitudes towards dating violence, has right perception about dating norms, and has higher perceived control over one's dating violence situation, it is more likely that the woman will intent and choose to leave and move on from the abusive relationship. This higher level of perceived control over one's dating violence problem can be achieved through the practice of spirituality derived from transpersonal psychology.

Therefore, from the literature review above, this research aims to give in-depth picture about dating violence experiences that occurred in Salatiga, Indonesia, using ethological perspective of attachment theory and transpersonal psychology as the main frameworks. This research also aims to create a preliminary conceptual model of dating violence prevention and protection in Salatiga, specifically, and in Indonesia, generally. This conceptual model will have a holistic perspective as its point of view.

\section{Method}

The current study used a qualitative approach with the method of case study. Case study research involves the study of a single case or multiple cases within a real-life setting [34]. According to Creswell and Poth [34], the case or cases can be an individual, a small group, organizations, or partnerships. Secondly, the participants in this study were women who experienced violence in dating relationships and were located in Salatiga and Solo, Indonesia, with an age range of 18-25 years. In this study, the selection of research participants was carried out based on the above criteria. Based on these criteria, the researchers found 4 women who were victims of violence in dating relationships.

Data sources known in qualitative research consist of two types, namely primary data sources and secondary data sources [34]. The source of primary data is information obtained directly from the participants who saw and were directly involved in the research conducted by the researcher. In this study, the following are sources of information that can be extracted and obtained by researchers in the process of collecting primary data, namely through: the process of in-depth interviews with victims of dating violence and observation of the behavior and statements of victims both verbally and non-verbally. In addition to collecting data with in-depth interviews, researchers also made observations and made field notes. The results of these observations will be made into a record of observation. Each observation note is a unit that shows the existence of one datum that explains events or situations that exist in other observational records [34]

In this study, the following are sources of information that can be extracted and obtained by researchers in the process of collecting the secondary data. Secondary data is a source of research data obtained by researchers indirectly through intermediary media (obtained and recorded by other parties) [34]. Furthermore, in order to ensure the suitability of the data obtained with the data provided by the information source, the researcher will conduct a member checking with the research participants [34]. Secondary data will be obtained by researchers from the people closest to the victims or who have witnessed acts of violence 
experienced by victims. In addition, researchers can also gather information about the background of the victims from their parents.

In accordance with the type of research determined, the data obtained through interviews in this study were analyzed using qualitative descriptive analysis [34]. This analysis is done by thoroughly describing the data obtained from the results of interviews and observations with the participants and other informants. After conducting the interviews, the researcher made a transcript of the interview results. Transcripts of interviews can be made, among others, by playing back the recording of the interview and writing the words verbatim. After the researcher writes the results of the interview into the transcript, the researcher then creates data categorization and data reduction by taking in the data that is in accordance with the research context and focus.

\section{Results \& Discussion}

This research has four main participants, namely, Sari, Dinda, Dahlia, and Mawar (all are pseudonyms). Attachment theory is used to capture and explain dating violence phenomena experienced by Sari and Dinda. While, Transpersonal Psychology is used to capture and explain dating violence phenomena experienced by Dahlia and Mawar. Doni and Rendi (both are pseudonyms) are Sari's and Dinda's boyfriend respectively, who are the perpetrators in the relationship.

\subsection{Insecure Attachment Pattern as the Basis of Victims' Survivorship}

Violence experienced by the Sari was in the form of verbal violence, sexual violence, and physical violence. Verbal violence experienced was in the form of name calling such as 'fat' ('bad', 'dog', 'bastard', 'pig'), monopolizing time (no time was given to hang out with friends), creating insecurities (by using the word 'whore', 'no longer attractive'), blaming (bestowing errors, accusing), manipulation (convincing the victim that the boyfriend is the best), making threats (threatened to leave her), interrogating (being jealous, possessive, controlling), breaking items (throwing plates, hitting walls and cabinets, breaking glasses). Whereas sexual violence experienced was coercion to commit sexual intercourse with the promise of being wed in the future and as proof of love between the two. Physical violence experienced by the participant was being slapped, kicked, and strangled.

Sari's father and Doni had similar characteristics, namely both of them committed acts of violence against women. The father commits violence to her mother, while Doni commits violence against Sari. Her response towards Doni in the situation of violence she experienced was also similar to the response of her mother towards her father's violence, which was silence, no resistance, and hoping that one day her partner would change. Seeing her mother experienced violence from her father also made Sari silent, although Sari felt sad and had a desire to stand in for and take the place of her mother's position in the violence situation. Another similarity is that both men figures are figures who can fulfill their financial needs.

Sari's mother as an attached figure has the same characteristics as Doni, they both have overprotective nature towards Sari. Her mother, since childhood, had forbidden Sari to play with her friends, even forbade her to attend her friend's birthday. Trivial things like the choice of clothes to wear were arranged by her mother. Sari believed that this was done by her mother for her own good. This characteristic was also shown by Doni towards Sari. Doni 
forbade Sari to hang out with her college friends, and not to be in one group with male friends while doing college assignments. Sari was also asked to limit her friends' circle. These separate but similar situations that emerged between Sari's relationship with her mother and Doni created deep feeling of sadness in Sari and turned into a feeling of loss.

The interpretation result for the father figure is that the father portrays a bad imprint on the concept of a typical man and hence, Sari did not have the right understanding of selecting a male partner. There is a sense of guilt towards the mother figure because Sari was helpless to help her when she experienced domestic violence. In turn, this feeling of guilt is manifested in the form of Sari's self-acceptance as a victim of violence. In addition, there is also an internalization of the concept of gender stereotypes in Sari's perception that puts women as a powerless individual that could not get out of the violence cycle. The interpretation results for the mother figure is that mothers create a concept of 'safety', with the need to protect or to give excessive protection. The excessive protection that Doni also gives can be easily accepted by Sari as a manifestation of love and attention.

The form of violence experienced by Dinda in her relationship with Rendi was verbal, emotional, and sexual violence. Verbal violence experienced was in the form of name calling such as ('stupid', 'dog', 'pig'), blaming (bestowing errors, accusing), making threats (threatened to get back with his ex-girlfriends), interrogating (being jealous, possessive, controlling), breaking items (throwing hand phone, hitting or slamming doors, throwing bottles). Emotional violence experienced is that Dinda was repeatedly cheated on, and lied to. The next form of violence is sexual violence. Sexual violence experienced by her was that Dinda was left pregnant and was demanded to get an abortion.

Dinda's father and Rendi have similar characteristics, both of them are loving figures and always ready to meet Dinda's needs. Although her father cannot express his feelings of affection with physical touch, Dinda can see that every hard work and earnestness of her father in his job as a form of love and affection for the family. Rendi also gave very similar treatment toward Dinda. Although Rendi continually had affairs, Dinda felt that Rendi was loving and always ready to accompany Dinda in her daily activities. Furthermore, Rendi was able to show his affection through physical touch which she did not get from her father.

Dinda's mother and Rendi have similar characteristics, that is, both of them always put the blame on Dinda and accuse Dinda of causing certain conflicts to arise in the relations or relationships with other people. Since childhood, her mother who seemed not to love her, always blamed Dinda for every fight between Dinda and her sibling. Dinda was never defended by her mother. The same thing also occurred in the relationship with Rendi, who always blamed Dinda for every affair he has been in with other girls. Dinda always felt that everything she does is wrong. The interpretation taken from the father figure is that Dinda is looking for a male/father figure who is merciful and alert in responding to her needs. There are indications that Dinda has her needs for physical touch fulfilled by Rendi; something that she did not get from her father. The comfort that Dinda is looking for in her relationship with Rendi is a form of substitution for the need of comfort that is missing from her relationship with her father. As for the interpretation of her mother, there is an indication that Dinda had developed feeling of inferiority, because since childhood, Dinda was always blamed by her mother. This inferior feeling is strengthened by Rendi's treatment towards Dinda. There is a 
habituation process to the feeling of inferiority and thus, Dinda no longer felt that it was a negative thing and as a consequence, this feeling did not disturb her anymore.

Sari's and Dinda's attachment patterns towards their parents can be identified as insecure. In both cases, the important point in the insecure attachment pattern is on the unavailability of a secure base for both participants to explore and understand that the world is a safe place to live and explore. As a result, the unavailability of this secure base causes the lack of interest in getting out of a situation considered comfortable, even when it is considered not safe for Sari and Dinda [25]. Moreover, Sari and Dinda are also lacking in power to overcome anxiety feeling towards separation with their partners, who has become their current attached figures. As a result of insecurity emerged from the attachment pattern with their parents, the feeling of anxiety towards separation cannot be well regulated by Sari and Dinda. Hence, both of them choose to stay in their current abusive relationship.

Attachment relation always contains emotional bond which is expressed through physical contact, words of love, and comfortable feeling from the fulfilled needs which are formed since childhood [23]. Sari's and Dinda's attachment experiences with their parents seem to not accommodate the physical and emotional contact that they need. Therefore, because of this insecure attachment, both of them facing difficulties in identifying and regulating their emotions. Hence, both of them could not understand the types of feelings/emotions, in what situation certain emotion should be expressed, and in what situation certain emotion should be managed. It hinders them to identify the inappropriate treatments from their partners. It also makes them always prioritize their relationships instead of dealing with the painful emotions that they felt.

The feeling of emptiness that Sari and Dinda felt and experienced because of insecure attachment patterns with primary attached figures also contributes in their survivorship in dating relationship. The absence of parental contact - especially the father as the oppositegender attached figure - since childhood, makes comfortable feeling from the physical contact that is given by their partners as an unfamiliar thing for them. Therefore, the comfortable feeling which their partners gave to them has become a difficult-to-treat reliance, especially for Dinda who has never experienced affectionate and loving physical contact from her parents. The emotion 'emptiness' also felt by Dinda, since her parents never expressed affection to her. Hence, she feels that all of the words and actions full of affections from Rendi fulfils the 'emptiness' she has since childhood. Therefore, she endures being repeatedly cheated by Rendi as long as he is still able to fulfil her needs.

\subsection{Decision Making to Leave Current Abusive Partner After Having Spiritual- Transcendental Experiences}

Based on the data analysis, various interesting results were found on how the participants decided to truly separate, had tried to bear the relationship and had tried to separate but failed. As Dahlia stated, Dahlia was still receiving violent verbal and emotional behavior when she tried to separate from her partner:

“After I broke up with him, he didn't want to accept it. He was just bluffing, in the end, he kept looking for me. He then felt sorry, asked to get back together, and was still able to terrorize me with text message. He could send me dozens of text messages if I did not reply, 
saying he could not sleep and so on. I could say that his messages were to intimidate me, using his words so that I would change my mind to get back together with him again. It was not imposing, somewhat... There were many unkind words in his messages which made me lose my peacefulness."

Both Mawar and Dahlia felt a girl's virginity is important, it is a symbol of women's honor, and that, it is very important to protect it. Therefore, virginity should be well guarded. Hence, when both of them lost their virginity with their boyfriend/partner, Dahlia and Mawar felt that they must and should naturally survive and continue to live with their partner despite of them being very violent. An example of the sentence that Dahlia said is like: "But, I already went too far (in the relationship/physically) ... Well, I was also afraid if there would not be someone else who would want to accept me if I've already been with someone else." "Well, we women, if we've done that who would want to be with us. Women should be able to protect it."

An interesting finding of this research is how psychological crises experienced by the participants actually brought them into spiritual and self-transcendence experiences, which then brings changes to both participants in responding to the perpetrators of violence and to the unhealthy relationships. The crisis experienced by the two participants were more or less the same, namely family problems, problems with friends, economic difficulties, and problems in the university education that they were currently pursuing. These crisis then prompted the two participants to then, find a transcendent figure (God) and spiritual experiences.

Dahlia said: "My dad is sick, and I don't have money, my thesis is problematic, well that's it. I didn't know what to do at that time, then I went to church". Mawar also stated: "Well, at that time my problems kept piling up. Lots of problems. Ummm, friendship problems, that kind of problem, I then reflected from these problems, why does it keep repeating again and again, the same kind of problems, and I don't know what is the way out, that's it, I know that I am wrong, but it's so hard to fix it, so hard to accept. Well, yeah, relationship problems, I had some disputes with friends, it was stressful and depressing. And my love life was like that, up and down, up and down. So does my academic condition, I mean it was messy because I had lost focus on my studies, I was short in improving my GPA, to the standard GPA which was 2.75, but my GPA was 2.5. And my mom retired but I haven't graduated yet. Then my sibling suggested that I should find God, so I tried".

The participants' spiritual experience is also able to guide them and to make them see themselves as more valuable. As stated by Dahlia: "God must have prepared a plan, a beautiful design for me. His design is not a design by accident."

Mawar also said: "Yes, we are valuable. So we should not see ourselves less just because we have a dark past, that we are not a virgin anymore, for example." Spiritual experiences that have built both participants in a positive way, also helped them to make and maintain a strong and firm decision; so that they do not return back to their former partners.

In the process of searches and evaluations of alternative solutions and problem-solving, the participants were also worshipping (i.e. prayer) and reflecting in order to obtain guidance from God, which is in this study is the transcendent figure, so that they would make a better decision. When the participants were making a decision to split up with their boyfriends, both participants felt that the decision they made was based on the instructions they interpreted 
implicitly through various encountered events and directions which came from God. The spiritual experiences that built both participants also helped them to maintain their decisions firmly, so that they did not return back to the former partners.

Dating violence can be physical and/or psychological abuse done by a partner in a relationship in order to gain control, dominance, and power over a partner [35]. Psychological abuse can include restricting the space of a partner, hurting partner by having an affair, and blaming partner for the relationship breakdown [36]. The current study found that this psychological abuse could start from overprotective actions from the perpetrators such as giving excessive attentions to the victims, accompanying everywhere the victims goes, and prohibiting victims from getting closer with friends from the opposite sex. These kinds of action are justified as normal and fine by the victims because they feel comfortable and considers it as a manifestation of affection and love in dating relationship. Consequently, it formed the reasons for the victims to stay in the psychological violence they experienced.

In decisions making for difficult and urgent problems, Atwater and Duffy stated that heavy mental processes are needed in the process of problem solving [37]. For the victims of dating violence, the decision to part from the partner can certainly be categorized as a heavy mental process. This can be seen from the many victims who find it difficult to separate, even when trying to, and finally return to their partners. Atwater and Duffy describe this as a nonsimple decision-making process where individuals tend to go through certain stages [37]. According to them, stages of individual decision making begins with how an individual realizes that she has a challenge or problem that must be solved. In the case of Dahlia and Mawar, it is an important point that they aware of experiencing a dating violence which needs to be resolve. If there is no complete awareness about this, then the next stages in the decisionmaking process will not happen at all.

One of the uniqueness found in the case of Dahlia and Mawar is how awareness of the problems that were faced truly occurred after the subject undergone a spiritual change. In the study of transpersonal psychology, spiritual change encouraged individuals to achieve higher self-functioning, thus the awareness of various life aspects was also getting better [38]. This process is called self-transcendence. Figure 1 showed that spirituality triggers one's awareness of the problems that must be solved, in this case the problem is dating violence. Spirituality and self-transcendence do not only trigger the awareness of the problem in the stages of decision making, it also played a role in the whole process. During the search and evaluation stages for alternative choices, spiritual changes experienced by Dahlia and Mawar, helped both of them to search for alternative sources and considerations related to their abusive relationships. The methods used by the two subjects in fulfilling spiritual experiences were praying, performing religious rituals, worshiping God, and reflection. Through these methods, Dahlia and Mawar then perceived various things that occurred around them as a sign from the universe or God about which decision regarding to their current relationships that they should choose, i.e. staying or leaving the abusive relationship. Dahlia and Mawar did not carry out the evaluation hastily. They seemed to pass through the stages well since they found various information or 'signs' from God. According to Atwater and Duffy, the absence of post decisional regret, i.e. after making a decision to leave the abusive relationship, is one of the important indications that the process of problem-solving has reached its completion [37]. 


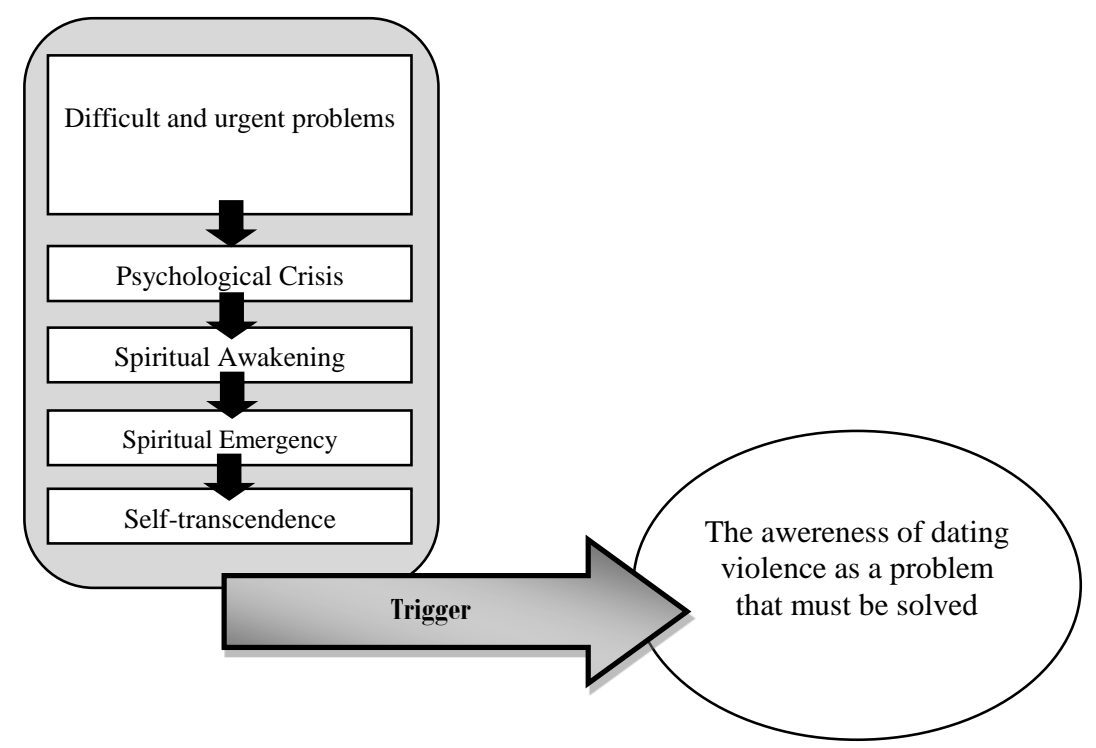

Fig 1. Awareness of Dating Violence Problems

\subsection{Conceptual Model of Dating Violence Prevention and Protection Using Bronfenbrenner's Ecological Theory as Framework}

Ecological theory views the development of a person from four different systems/layers, namely microsystem, mesosystem, exosystem, and macrosystem [31]. The core point in this theory is that the study of human development within an environment must be person-centred and specific the context of time [31]. According to Bronfenbrenner [39], these are the four systems that from the ecological model. Micro system is a subsystem that have direct interaction with individuals, which consists of families, peers, schools and their environment. Mesosystem includes interactions between microsystems. Exosystem includes larger social system in which individual is not directly involved with but can still have an effect and impact, such as the community in which an individual lives. Then, macro system is the outermost layer of the individual's environment such as culture, customs, and law within a society.

In the model in figure 2, there are several layers surrounding the victim and the perpetrator of dating violence such as family, peer group, school, home community, and wider society in general. Attachment theory has an important role in the victim family and perpetrator family layer. As stated by Bowlby [24], there are mainly 2 type of attachment that occurred in the family layer, namely secure attachment and insecure attachment. In accordance to the findings of the current research, insecure attachment with primary attachment figures could create and result in the lack of attachment security, and potentially would result in the occurrence of unhealthy/ abusive relationship pattern in future. Therefore, as an implication, it is important for parents to nurture and grow close relationship with their 
children in order to create secure attachment between parents and children. This will become an effective early prevention strategy to help reducing dating and domestic violence in the future.

In terms of transpersonal psychology, this aspect is located within individuals (i.e. the perpetrator and the victim), that are located within the microsystem. Transpersonal psychology encourages self-transcendence that helps individuals to assess themselves more positively, so that the negative impact that had arisen and become one of the factors preventing the subject to leave and move on from the perpetrator can be lessen. This encourages the individual (i.e. victim) to have a more mature self-function, able to assess herself more positively, which in turn makes her to have hope for a better future. With the better maturity and function gained from spiritual experience, the decision making process in an individual can help her to better evaluate the alternative choices that she has. In-depth study and application of transpersonal psychology will greatly help victims to make decisions in a more specific, in-depth, and contextual manner. The depiction of problem from transpersonal psychology perspective triggers individual's awareness of the current problem that she has to solve, and in this case is dating violence. Not only did they trigger awareness about the problem, in the decision making stage, it was also found that spirituality and self-transcendence also played a role in the process of helping victims to leave and move on from current abusive relationship.

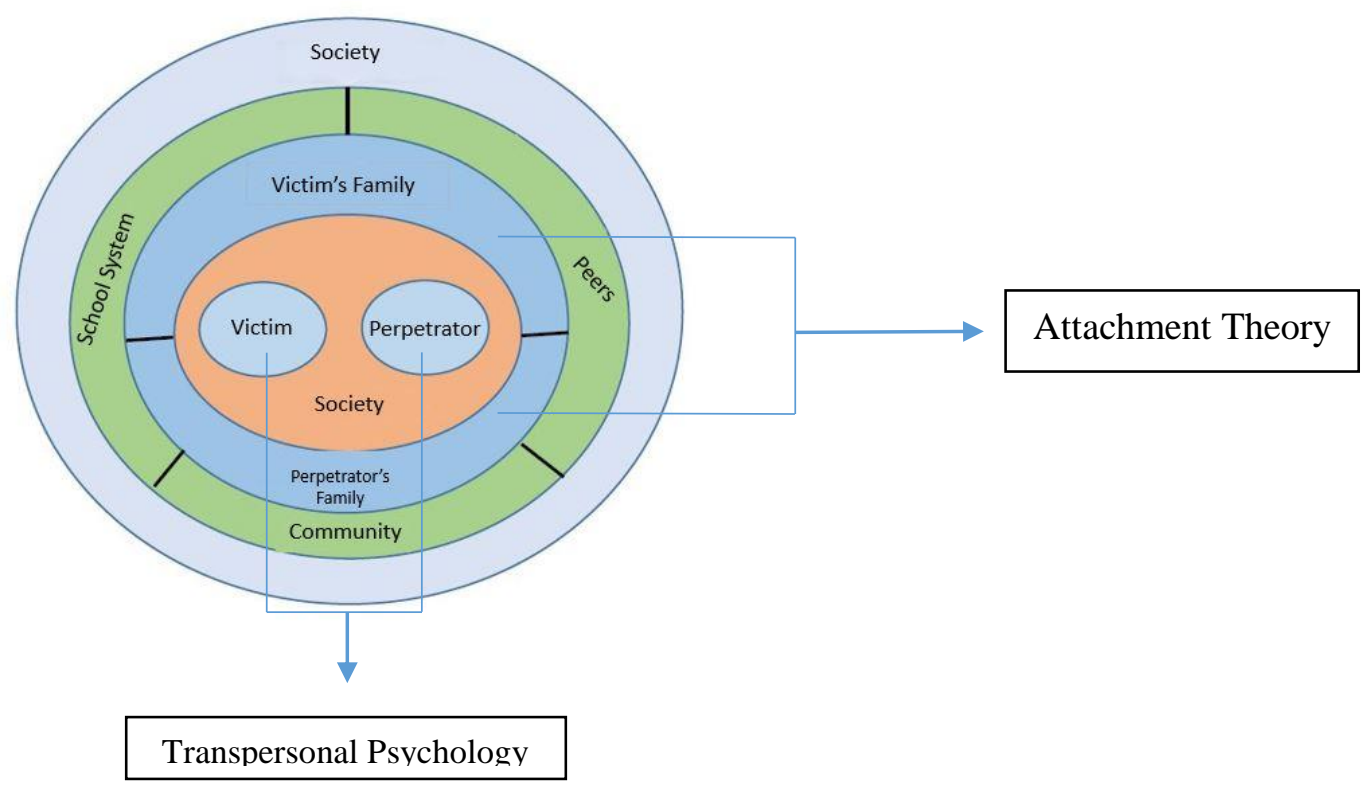

Fig 2. The Role of Attachment Theory and Transpersonal Psychology within Bronfenbrenner's Model

\section{Conclusion}

Women who become victims of violence in dating relationships could potentially have developed insecure attachment style with their parents in the past, and this insecurity affects 
their survivorship in abusive relationships. Victims who grew with an insecure attachment style tend to develop acute anxiety when dealing with separation, therefore they choose to stay in abusive relationships. Physical and emotional needs such as physical touch, love words, and attention, are needs that must be fulfilled for insecure women, even though they have to be compensated with pains. Therefore, education for parents and their children is necessary to help them understand the central role of children's attachment in shaping their sense of security and developing their security, based on the concept of "love", to prevent them from becoming victims of violence in the future.

Furthermore, several conclusions may be drawn from the present study. First, violence in dating relationships takes place because there was overprotective behavior from the male partner which was justified by the victim. The victim feels comfortable with this behavior, because it is seen as something that is normal in dating. Secondly, victims' spiritual experience arising from the psychological crisis, making them self-transendent, may help to improve how they function. This was shown by the victims' enhanced abilities in discerning violence-related issues that they had been experiencing for years after the intervention and employing methods such as praying, performing religious rituals, worship, and reflection. Through this, the victims continued to seek guidance and support in dealing with their problem and eventually made a decision to separate from their abusive dating partner. The spiritual experience was shown to aid the subjects to go through critical stages in the decision making, i.e. when evaluating alternatives and reassessing the decision that they made. With no post-decisional regret indicated, it can be said that the victims believed that the decision to part with their violent partner was correct.

The implication of the current research is, firstly, prevention of dating violence occurrence in the future, can be started early from home by giving children a secure, loving, affectionate relationship. Hence, this will create a secure attachment between children and parents as their primary figure of attachments. Secondly, spiritual experiences can play an essential role and help individuals to become aware about their dating violence problems, find a definite solution, and move on from dating violence problems.

For the direction of future research, it is important to apply the conceptual model based on the ecological theory to other aspects in mesosystem and exosystem layer such as family/parenting and peer groups in broader community. Future research can focus to give intervention to victim's and/or perpetrator's family, using family therapy or systemic therapy. Intervention can also be given to the victim's and/or perpetrator's peer groups. It is also essential to give treatment/therapy to the perpetrator in order to stop the vicious cycle of dating violence.

In conclusion, this research examined violence in dating relationships that is committed by one partner, further research may be conducted to examine relationships where such behavior is mutually committed by both partners. Victims are encouraged to be able to develop a balanced perspective in dating by always being aware of psychological violence that might occur, prevent its occurrence, and not blaming themselves if the violence occurred. They should also open themselves for discussing their problem with their parents or someone trustworthy. Thirdly, victims of violence often are not aware of the fact that they are experiencing violence in dating relationship, especially psychological and verbal violence. It is therefore recommended that the Indonesian National Comission for Violence Against Women and Satya Wacana Christian University Faculty of Psychology and related institutions give more attention to dating violence cases by giving counseling services and share comprehensive informations on dating violence to schools, university campuses, and the general public in Indonesia. 


\section{References}

[1] World Health Organization, "Global and regional estimates of violence against women: Prevalence and health effects of intimate partner violence and non-partner sexual violence," World Health Organization, 2013. [Online]. Available: https://www.who.int/reproductivehealth/publications/violence/9789241564625/en/. [Accessed: 22-Feb-2019].

[2] L. E. Saltzman, J. L. Fanslow, P. M. McMahon, and G. A. Shelley, "Intimate partner violence surveillance: Uniform definitions and recommended data elements," in Centers for Disease Control and Prevention, National Center for Injury Prevention and Control, Atlanta, 2002.

[3] L. Eshelman and A. A. Levendosky, "Dating violence: Mental health consequences based on type of abuse," Violence Vict., vol. 27, no. 2, pp. 215-28, 2012.

[4] D. Exner-Cortens, J. Eckenrode, and E. Rothman, "Longitudinal associations between teen dating violence victimization and adverse health outcomes," Pediatrics, vol. 131, no. 1, pp. 7178, 2013.

[5] M. C. Black et al., The National Intimate Partner and Sexual Violence Survey (NISVS): 2010 Summary report. Atlanta, GA: National Center for Injury Prevention and Control, Centers for Disease Control and Prevention, 2011.

[6] Komnas Perempuan, "Lembar fakta dan poin kunci Catatan Tahunan (CATAHU) Komnas Perempuan Tahun 2018," Komnas Perempuan, 2018. [Online]. Available: https://www.komnasperempuan.go.id/read-news-lembar-fakta-dan-poin-kunci-catatan-tahunancatahu-komnas-perempuan-tahun-2018.

[7] Komnas Perempuan, “Kekerasan dalam pacaran,” Komnas Perempuan, 2017. [Online]. Available: https://www.komnasperempuan.go.id/read-news-kekerasan-dalam-pacaran. [Accessed: 29-Mar-2019].

[8] S. F. Lewis and W. Fremouw, "Dating violence: A critical review of the literature," Clin. Psychol. Rev., vol. 21, pp. 105-127, 2001.

[9] Komnas Perempuan, "Kekerasan terhadap perempuan: Negara segera putus impunitas pelaku, catatan KTP 2014,” Jakarta, 2015.

[10] Komnas Perempuan, "Kekerasan terhadap perempuan meluas: Negara urgen hadir hentikan kekerasan terhadap perempuan di ranah domestik, komunitas dan negara, catatan KTP tahun 2015," Jakarta, 2016.

[11] Komnas Perempuan, "Labirin kekerasan terhadap perempuan: Dari gang rape hingga femicide, alarm bagi negara untuk bertindak tepat, catatan KTP 2016," Jakarta, 2017.

[12] Komnas Perempuan, "Tergerusnya ruang aman perempuan dalam pusaran politik populisme, catatan KTP 2017," Jakarta, 2018.

[13] M. A. Sutherland, "Implications for violence in adolescent dating experiences," JOGNN J. Obstet. Gynecol. Neonatal Nurs., vol. 40, pp. 225-234, 2011.

[14] N. Glass, N. Fredland, J. Campbell, M. Yonas, P. Sharps, and J. Kub, "Adolescent dating violence: Prevalence, risk factors, health outcomes, and implications for clinical practice," JOGNN J. Obstet. Gynecol. Neonatal Nurs., vol. 32, no. 2, pp. 227-238, 2003.

[15] D. K. Eaton, K. S. Davis, L. Barrios, N. D. Brener, and R. K. Noonan, "Associations of dating violence victimization with lifetime participation, co-occurrence, and early initiation of risk behaviors among U.S. high school students," J. Interpers. Violence, vol. 22, pp. 585-602, 2007.

[16] X. B. Arriaga, "Adolescents dating: Do adolescents follow in their friends' or their parents' footsteps?," J. Interpers. Violence, vol. 19, no. 2, pp. 162-184, 2004.

[17] N. V Benokraitis, Marriages and families: Changes, choices, and constraint, Edisi 2. New Jersey: Prentince-Hall, 1996. 
[18] A. L. Cantos, P. H. Neidig, and K. D. O'Leary, "Injuries of women and men in a treatment program for domestic violence," J. Fam. Violence, vol. 9, no. 2, pp. 113-124, 1994.

[19] L. R. Collins and J. W. White, "College females decision to stay or leave an abusive relationship: A test of the investment model," The University of North Carolina at Greensboro, 2011.

[20] M. K. DeGenova and P. Rice, Intimate relationship, marriage and family, Edition 6. Boston: McGraw-Hill, 2005

[21] I. Ajzen, "Perceived behavioral control, self-efficacy, locus of control, and the theory of planned behavior," J. Appl. Soc. Psychol., vol. 32, pp. 665-683, 2002.

[22] K. A. Peterson, "An evaluation of two dating violence prevention on a college campus," John Hopkins University, 2015.

[23] J. W. Santrock, Life-span development. New York: The McGrawHill Companies, 2012.

[24] J. Bowlby, Attachment and loss: Loss, sadness, and depression. London: Penguin Books, 1980.

[25] J. Bowlby, Attachment and loss: Separation. London: Penguin Books, 1973.

[26] J. W. Santrock, Life-span development: Perkembangan masa hidup, Edisi 5. Jakarta: Erlangga, 2002.

[27] V. A. Foshee et al., "Examining explanations for the link between bullying perpetration and physical dating violence perpetration: Do they vary by bullying victimization?," Aggress. Behav., vol. 42, no. 1, pp. 66-81, 2016.

[28] K. J. Vagi, E. F. Rothman, N. E. Latzman, A. T. Tharp, D. M. Hall, and M. J. Breiding, "Beyond Correlates: A Review of Risk and Protective Factors for Adolescent Dating Violence Perpetration," J. Youth Adolesc., vol. 42, no. 4, pp. 633-649, 2013.

[29] J. M. Tschann, L. A. Pasch, E. Flores, B. VanOss Marin, E. Marco Baisch, and C. J. Wibbelsman, "Nonviolent aspects of interparental conflict and dating violence among adolescents," J. Fam. Issues, vol. 30, no. 2, pp. 295-319, 2009.

[30] J. Davis, “An overview of transpersonal psychology," Humanist. Psychol., vol. 31, no. 2-3, pp. 6-21, 2003.

[31] U. Bronfenbrenner and P. A. Morris, "The bioecological model of human development," in Hanbook of child psychology: Theoretical models of human development, 6th ed., W. Damon and R. M. Lerner, Eds. New York: Wiley, 2006, pp. 793-828.

[32] R. Frager and J. Fadiman, Personality and personal growth, Edition 6. Prentince Hall, 2005.

[33] L. Karsner, "Belief about partners personal qualities that facilitate intimacy," J. Marriage Fam., vol. 7, pp. 35-36, 2001.

[34] J. W. Creswell and C. N. Poth, Qualitative inquiry and research design: Choosing among five approaches. Thousand Oaks, CA: Sage publications, 2017.

[35] J. Murray, Abusive dating relationships. United States: HarperCollins Publishers, 2007.

[36] J. Murray, But I love him. United States: HarperCollins E-book, 2007.

[37] E. Atwater and K. G. Duffy, Psychology for living: Adjustment, growth, and behaviour today, Edition 8. New Jersey: Upper Saddle River Inc, 2004.

[38] D. J. Perry, "Self-transcendence: Lonergan's key to integration of nursing theory, research, and practice," Nurs. Philos. J., vol. 5, no. 1, pp. 67-74, 2004.

[39] U. Bronfenbrenner, Making human beings human: Bioecological perspectives on human development. Thousand Oaks, CA: SAGE Publications., 2005. 